If the sleepwalking and night terrors are isolated problemsand in childhood this is most often the case-the reasons for parental anxiety should be determined. Reassurance may be given about the usually benign long-term outcome, but symptomatic advice will often be helpful. Establishing regular bedtime routines and avoiding frightening television programmes may help prevent sleepwalking and night terrors. "Proofing" the environment to prevent accidental injury to sleepwalkers is well worth while. As many as $24 \%$ of adult sleepwalkers have reported injuring themselves, ${ }^{7}$ and though the risk may be less in childhood it is not negligible. The view of the sleepwalking episode as an acted-out dream has been challenged, ${ }^{8}$ but nevertheless the parents should be encouraged to talk with the child and to share and if possible understand his or her anxieties about the episodes and other possible stresses. Finally, in cases of frequent sleepwalking the risk of injury may justify a trial of treatment with diazepam. ${ }^{8}$

${ }^{1}$ Bixler EO, Kales A, Soldatos CR, Kales JD, Healey S. Prevalence of sleep disorders in the Los Angeles metropolitan area. Am F Psychiatry 1979; 136: $1257-62$.

2 Anders TF, Weinstein P. Sleep and its disorders in infants and children: a review. Pediatrics 1972;50:312-24.

${ }^{3}$ Kales A, Jacobson A, Paulson MJ, Kales JD, Walter RD. Somnambulism: psychophysiological correlates I. All-night EEG studies. Arch Gen Psychiatry 1966;14:586-94.

${ }^{4}$ Bakwin H. Sleep-walking in twins. Lancet 1970 ;ii:446-7.

5 Kales A, Soldatos CR, Bixler EO, et al. Hereditary factors in sleepwalking and night terrors. Br $\mathcal{F}$ Psychiatry 1980;137:111-8.

${ }^{6}$ Kales A, Paulson MJ, Jacobson A, Kales D. Somnambulism: psychophysiological correlates II. Psychiatric interviews, psychological testing and discussion. Arch Gen Psychiatry 1966;14:595-604.

Kales JD, Humphrey FJ, Martin ED, et al. Clinical characteristics of patients with sleepwalking: further studies. Sleep Research 1978;7:192.

${ }^{3}$ Guilleminault C, Anders TF. Sleep disorders in children. Adv Pediatr $1976 ; 22: 151-74$.

\section{Born again and live longer?}

As the "born-again" evangelical movement swept through the United States it gathered up both of the recent leading Presidential candidates. We are also told that Americans are living longer. ${ }^{1}$ Are the two phenomena related, and if so, should survival be calculated from the first or the most recent birth? So far neither "born-again" nor any similar improvement in longevity in middle age seems to have reached Britain. If they did, not only would campaigning politicians need to take notice but so also would the army of demographers, statisticians, registrars of births, marriages, and deaths-and in particular the Registrar General himself, who sits in solitary splendour at his command post in the Office of Population Censuses and Surveys armed only with his swaggerstick and adding machine.

Over the one and a half centuries of his command the annual reports from the Registrar General have always been of a special quality among Government statistics. The money supply may be miscalculated by the odd thousand million pounds, or figures for exports, unemployment, or cost of living may need to be recalculated or readjusted; but the citizens of England and Wales have rested content that each and every one of them would be mentioned in the annual dispatches from the Registrar General, once at birth and once at death. These vital statistics, extending back so many years, are not just crude estimates but real numbers, counted laboriously to six digits and more of unquestioned accuracy, and truly the envy of the world.
Could such an established tradition be mistaken? Is it not time that this early Victorian rationalism was replaced by a new policy with a laid-back approach to metaphysics? All the current publications assume, naively, that we are all born once each, and then at exactly the same early age, that we all age uniformly according to the number of calendar years elapsed, and that life is finite and measurable and extends only as far as death, which occurs to all of us, and then once only. If divorce and multiple remarriages were established in the 1940s and 1950 s, resuscitation from sudden death became commonplace in the 1960 s and 1970 s, so perhaps multiple rebirth will be the pattern of the 1980s. If so, the Registrar General must reconsider his limited range of publications on numbers of births, marriages, and deaths, and age at death, and extend them in the interests of comprehensiveness and commercial profit. His admirable decennial supplements on occupational and area mortality and on cancer should be joined by others on age since last reincarnation, survival after first death, frequency of rebirth, aeons in purgatory, and many more. To save having to retrain him and his staff-officers, he could be helped by a specialist Civil-Service task-force of mediums, spiritualists, and clairvoyants; these could be usefully seconded from the Treasury.

Meanwhile what evidence is there that a spiritual rebirth or a virtuous life leads to longer survival on earth? Unfortunately neither the Registrar General in his decennial censuses and his death certificates nor the numerous designers of cohort studies of risk factors have bothered to measure the state of grace of the subjects whose survival they were plotting. The nearest approaches to this problem are in studies of occupation and mortality. While occupation may not relate direct to virtue, there is some relation to poverty, chastity, and obedience. The Registrar General's decennial supplements on occupational mortality ${ }^{2-4}$ have always shown higher mortality in single than married persons. It is not too surprising, therefore, that a comparison ${ }^{2}$ of Church of England clergy with Roman Catholic priests showed a higher mortality in the latter, whose mortality rates were no better than average for all employed men. Single women in religious orders had mortality rates that were only slightly better than average for single women in the $1961^{3}$ report and considerably worse in 1970-2. ${ }^{4}$ Similarly obedience does not identify either the police or the armed Forces as at low risk; if anything the reverse.

What about poverty? Social-class gradients in mortality suggest that it, too, may be harmful, while in England and Wales the lower mortality of the clergy compared with other professions over the past 50 years seems to be disappearing at the same time as their comparative living standards may have dropped. On the other hand, a series of studies in the United States suggest that Baptist, Lutheran, Presbyterian, and Episcopalian clergymen have lower death rates than those for white clergymen and all white males generally. ${ }^{5-9}$ Rational explanations for these differences and trends might be sought in the way clergy and others are selected and in their smoking and drinking habits and accident proneness. The indications, however, are that those who are securing their treasure in heaven rather than on earth may not live much longer; perhaps the years pass more slowly. Fortunately, even if our politicians were to be born again before each election their term of office on earth would still be limited.

${ }^{1}$ Havlik RJ, Feinleib M, eds. Proceedings of the conference on the decline in coronary heart disease mortality. Washington: US Department of Health, Education and Welfare, 1979. (NIH 79-1610.)

2 Registrar General. Decennial supplement for England and Wales 1951. Occupational mortality. London: HMSO, 1958. 
${ }^{3}$ Registrar General. Decennial supplement for England and Wales 1961. Occupational mortality tables. London: HMSO, 1971.

4 Registrar General. Decennial supplement for England and Wales 1970-72. Occupational mortality. London: HMSO, 1978. (OPCS Series DS No 1.)

${ }^{5}$ King H, Bailar JC III. Mortality among Lutheran clergymen. Milbank Mem Fund $Q$ 1968;46:527-48.

${ }^{6} \mathrm{King} \mathrm{H}$. Health in the medical and other learned professions. $\mathcal{F}$ Chronic Dis $1970 ; 23: 257-81$.

${ }^{7}$ King H. Clerical mortality patterns of the Anglican communion. Soc Biol 1971;18:164-77.

${ }^{8}$ King H, Zafros G, Hass R. Further inquiry into Protestant clerical mortality patterns. F Biosoc Sci $1975 ; 7: 243-54$.

9 Locke FB, King H. Mortality among Baptist clergymen. $f$ Chronic Dis 1980 ;33:581-90.

\section{More anthropology and less sleep for medical students}

Young graduates from different medical schools have more similarities than differences. Those from ancient institutions seem indistinguishable in attitudes and attainments from the products of schools in which the paint is not dry and the second professor of surgery not yet born. Yet great battles are fought over what subjects should be taught. The alleycats of psychology, sociology, epidemiology, statistics, anthropology, communications studies, computer science, and even general practice and community medicine are hardly visible for flying fur in the scrap for time and status. Meanwhile, the lions and tigers of medicine-surgery, anatomy, physiology, and the like - count their blessings and guard their cubs. If the shrinking gap between full qualification and retirement is not to disappear altogether and students are to be allowed to sleep at nights then faculties must consider carefully what they want to teach.

Medical anthropologists are the latest group to raise their voices asking for room in the curriculum. A joint meeting in Edinburgh of the British Medical Anthropology Society and the sibilant Edinburgh Transcultural Psychiatry Society suggested that medical students could learn much that was useful from social anthropology. As Professor J E Cooper from Nottingham pointed out, there are no scientific studies to tell us whether more neuroanatomy or more medical anthropology makes better doctors (nor, indeed, whether more anatomy and less rugby does-some would doubt it). Therefore we must assess the medical anthropologists' arguments (good) and feel the strength of their political muscle (weak).

What is anthropology and why should medical students be exposed to it ? (They cannot be taught it in the time available.) Definitions of anthropology are vague: a common one, that it is the science of man in its widest sense, might be said to include the whole of medicine; another, that it is the study of man in his environment, makes its exclusion from medical school curricula seem remarkable. An often-repeated comment on anthropology - that it is the most scientific of the humanities and the most humane of the sciences-seems to place it right alongside medicine. Medical anthropology is better defined as "what medical anthropologists do," and they do a lot: they study different cultures' beliefs about illness, health, and treatment; health care organisation; and the behaviour of various groups (for instance, doctors and patients), and the communication among them. The groups studied include not only the inhabitants of exotic islands but also, as papers presented at the conference made clear, ordinary people-patients in a Middlesex general practice, Aberdonian fishwives, and the Parisian jet set. Anthropological methods are designed less to measure and more to "get under the skin" of the group being studied; classically, an anthropologist will live among the people he is studying, speak and eat as they do, and fit in as much as possible. Anthropological studies are often lists of quotations rather than statistics-a change that may be refreshing for the student more interested in people than science.

Teaching anthropology in medical schools could be seen as remedial education for the middle classes: for a doctor educated at Westminster, Cambridge, and Guy's a football-obsessed Mancunian may be as strange as a Zulu. At the conference $\mathrm{Dr}$ Cecil Helman's paper on patients in a general practice and $\mathrm{Dr}$ Mildred Blaxter's paper describing the ideas about illness of two generations of working class Aberdeen women showed that these groups have complex ideas about illness, its causes, and its treatment. These ideas are often quite different from those of doctors, who no matter where they are practising will only benefit from understanding the patient's beliefs. In such areas as the East End of London-where, as Dr Jane Jackson described, such diverse groups as orthodox Jews, Pakistanis, Rastafarians, National Front enthusiasts, art students, "winos," and a few remnant cockneys live-doctors will find it hard to treat effectively without some insight into these people's views of illness and health; and this can best be achieved through anthropology. Also studies of doctors' behaviour, reactions to modern hospitals, and cultural variations in attitude to mental illness can give breadth to the thinking of students.

The introduction of anthropology along with many other less traditional disciplines into the curriculum is resisted in many medical schools. The usual argument is that this would be all very well but there is simply no time available. Professor Cooper thought that other problems were that doctors, academics, and surgeons are themselves legitimate subjects for anthropological study and they may find this threatening. Furthermore, anthropology is more concerned with values and attitudes than "facts," which have traditionally been the main substance of the medical curriculum. But in some medical schools-for instance, Aberdeen - the students have asked to be taught anthropology-though sometimes when it arrives they find it hard to comprehend. Professor Cooper suggested from his experience in Nottingham that it could best be taught by generalists in small doses using mostly medical examples.

Certainly medical students would benefit from learning to see illness and modern medicine from the patients' point of view. One thing not mentioned at the conference, however, is that another way of understanding something of how others see the world is by reading novels, which almost by definition are easier to read than anthropology. Works by authors such as Dickens, Wesker, Steinbeck, Orwell, Zola, Sillitoe, Berger, and Dostoevsky both entertain and educate.

\section{An endangered species}

Among the species registered as endangered in the coming decade should be included the independent expert-in its habitat as adviser to Government. One threat has come from Mr Patrick Jenkin. Twice this year he has rejected reports based on external analysis of medicosocial needs: on in equalities in health ${ }^{1}$ and on perinatal mortality. ${ }^{2}$ Perhaps flat, insensitive rejection of independent outside assessments is part of his personal philosophy: but the long-term result must be a further devaluation of the status of scientific 